\title{
A study on Arch Widths of Bangladeshi Adult Subjects with Class II-2 malocclusion compared to those with Class II div1 malocclusion and Normal Occlusion.
}

\author{
Rana $M^{1}$ BDS, FCPS \& Hossain $M^{2}$ BDS, PhD
}

\begin{abstract}
Aim : To evaluate the transverse discrepancy in different malocclusion groups. Also to test the hypothesis that models with Class II division 2 malocclusion may have mean maxillary arch widths significantly smaller than those with normal occlusions and significantly larger than those with Class II division 1 malocclusion.. Thus the proposed study will generate interest among the orthodontists for further study over the transverse discrepancy of our patients and guide them to establish effective treatment strategy and their management.
\end{abstract}

Methods : This study was a cross sectional study conducted among the dental casts of 150 patients and students of the Department of Orthodontics and Dentofacial Orthopedics, Dhaka Dental College and Hospital. Both male and female were included. The first group consists of 50 pair of study models with permanent dentition and diagnosed as Class I (normal) occlusion. The second group includes another 50 pair of dental casts with permanent dentition and diagnosed as Class II division 1 malocclusion. And third group includes another 50 pair of dental casts with permanent dentition and was diagnosed as Class II division 2 malocclusion. This group of malocclusion was again subdivided into two categories, Class II division 2 malocclusion with crowding and Class II division 2 malocclusion without crowding. The Student's $t$-test was used to analyze the data. In this analytical test the level of significance $p$ value $<0.05$ was considered significant.

Results: No Statistically significant difference was observed in the maxillary inter canine, inter first premolar and inter first molar widths between class-I and Class-II div-1. Significant differences were observed between two groups. In case of mandibular inter first molar widths ( $p$ value $=0.001$ ), and also differences in case of mandibular inter canine, inter first premolar and inter first molar widths between Class-I and Class II div 2 malocclusion p value respectively .01, 0.002,0.01.

Conclusion: This study helps in determining possible differences in the dental arch widths of Bangladeshi people in Class II div 2 adults compared to adults with Class II div 1 and normal occlusion may be an important aid in further understanding of dentoalveolar characteristics of these conditions, as well as improving their management.

Key Words : Arch Width, Class II div 2 malocclusion, Class II div 1 malocclusion, Normal Occlusion (Bangladesh Journal of Orthodontics and Dentofacial Orthopedics, April 2013; Vol-3, No. 2, p 12-17)

\section{INTRODUCTION}

Class II malocclusion is reported as the most frequently seen skeletal disharmony in orthodontic population. 1,2,3 Cephalom -etrically it is characterized by a variety of skeletal patterns. Class II division 1 malocclusion may be related with mandibular retrognathism ${ }^{4,5}$ maxillary prognathism ${ }^{6}$ or, a combination of both ${ }^{7}$ but the cranial base may also be involved.6,7 In an effort to describe the typical Class II division 1 malocclusion, the following are the characteristics $^{8}$ In frontal view face is usually oval (Mesocephalic to Dolichocephalic). A convex profile with posteriorly divergent face. There is incompetent or stretched upper lip due to proclined upper incisors. Lower lip is everted. There is lack of lip seal. Intraorally, Class II molar relationship, proclined upper incisors and an increased overjet. An exaggerated curve of Spee and upper arch is usually narrow and V-shaped. There is deep bite which is usually traumatic in nature. Other features may be an open bite, cross bite, crowding etc.

Heredity seems to play an important role in the development of this type of malocclusion. ${ }^{9}$ According to Bassigny F 1983 , the etiology of Class II division 1 malocclusion in 
dolichocephalic, occlusion may be determined hereditary or functional factors (activity of the tongue, activity of facial muscles or, head posture). ${ }^{10}$ On the other hand, in brachycephalic people, functional factors (lower lip or, tongue activity) do not seem to be important. Local environmental factors (eg. premature exfoliation of primary teeth) seem to affect a Class II malocclusion of dental rather than of skeletal etiology ${ }^{11}$, Class II malocclusion problems are often combined with jaw and dental arch discrepancies on the sagittal as well as on the transverse or vertical planes. ${ }^{12}$ Orthodontic treatment of the malocclusions and especially non extraction treatment plans, often include expansion of the upper dental arch.13-16 Dental arch dimensions change during treatment as well as during the retention phase. Nevertheless, research studies about dental arch dimensions during the active growth period are few and concern only certain parameters. Papageorgiou et al. 1998, studied dental dimensions in people with Class II division 2 malocclusion. Some authors made a comparative study on arch widths between Class II division 2 and Class II division 1 malocclusion. Concerning Class II division 1 malocclusion some studies are available. ${ }^{17}$ A very recent study conducted over white Brazilians to compare the arch widths with normal occlusion and Class II division 1 malocclusion. Uysal T et al. 2005, Staley et al. 1985, as well as Buschang et al. 1994, examined dental arch differences in adults. ${ }^{18-20}$ Toutountzakis N 1989, examined upper interfirst molar widths in children ${ }^{21}$, Frohlich FJ 1962 states the upper and lower inter first molar and inter canine widths 22 , whereas Ingerval B and Lennartsson B 1972 examined inter first molar widths and length of both dental arches. ${ }^{7}$ Baccetti et al.1996 studied the changes and widths discrepancies of both dental arches at the region of primary and permanent molars on dental casts. ${ }^{23}$ Bishara et al. 1996a studied length changes and arch discrepancies of both dental arches in Class II division 1 malocclusion. 12

In Bangladesh, no studies been conducted except Rahman MM 2007 and Islam MM 2011.24,25 Till now, our efforts were confined to isolated case management and study the prevalence of different malocclusions. A definite study in determining possible differences in the dental arches widths of Bangladeshi people in Class II div 2 adults compared to adults with Class II div 1 and normal occlusion may be an important aid in further understanding of dentoalveolar characteristics of these conditions, as well as improving their management.

\section{OBJECTIVES}

1. To test the hypothesis that models with class II division 2 malocclusion may have mean maxillary arch widths significantly smaller than those with normal occlusions and significantly larger than those with Class II division 1 malocclusion.

2. To evaluate the transverse discrepancy in different malocclusion groups.

3. These results will guide them to establish effective treatment strategy and their management.

\section{MATERIALS \& METHODS}

This study was a cross sectional study conducted among the dental casts of 150 patients and students of the Department of Orthodontics and Dentofacial Orthopedics, Dhaka Dental College and Hospital. Both male and female were included. 150 pair of study models were selected from patients and students of the Orthodontics \& Dentofacial Orthopedics Department of Dhaka Dental College \& Hospital and were divided into three groups. The first group consists of 50 pair of study models with permanent dentition and was diagnosed as Class I (normal) occlusion. The second group includes another 50 pair of dental casts with permanent dentition and was diagnosed as Class II division 1 malocclusion. And third group includes another 50 pair of dental casts with permanent dentition and diagnosed as Class II division 2 malocclusion. This group of malocclusion was again subdivided into two categories, Class II division 2 malocclusion with crowding and Class II division 2 malocclusion without crowding. Comparison made on inter canine, inter first premolar and inter first molar widths of both dental arches.
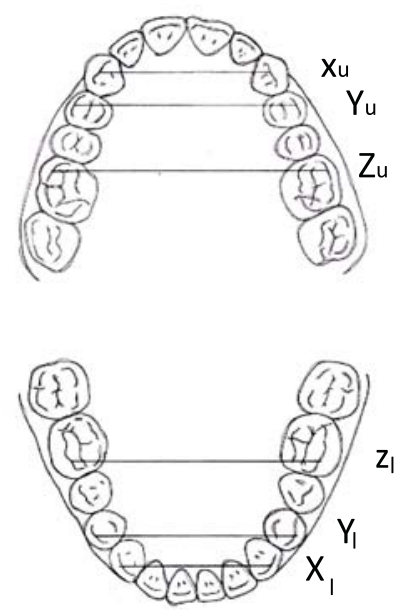

Fig-1 shows inter canine, inter first premolar and inter first molar widths of both Maxillary and Mandibular arches. 
A study on Arch Widths of Bangladeshi Adult Subjects with Class II-2 malocclusion compared to those with Class II-1 malocclusion and Normal Occlusion.

\section{Maxillary measurements}

1. Maxillary intercanine width: $\mathrm{xu}$

Distance between the cusp tips of right and left maxillary permanent canines.

2. Maxillary interfirst premolar width: yu

Distance between the buccal cusp tips of right and left maxillary permanent first premolar.

3. Maxillary interfirst molar width:zu

Distance between the mesiobuccal cusp tips of right and left maxillary permanent first molar.

\section{Mandibular measurements}

1. Mandibular intercanine width : $\mathrm{xl}$

Distance between the cusp tips of right and left mandibular permanent canines.

2. Mandibular interfirst premolar width: yl

Distance between the buccal cusp tips of right and left mandibular permanent first premolars.

3. Mandibular interfirst molar width : $\mathrm{zl}$

Distance between the mesiobuccal cusp tips of right and left mandibular permanent first molars

\section{DATA COLLECTION AND PROCESSING}

After collection of data, the obtained data were checked, verified. These were entered and analyzed in a personal computer using the SPSS (statistical package for social science) software, version 12.0 (statistical package for social science SPSS Inc. Chicago, USA) Appropriate statistical tests were done depending on the distribution of data.

\section{RESULTS}

The occlusion of these subjects were class 1 (normal) occlusion, Class II division 1 malocclusion and class II division 2 malocclusion. Class II division 2 malocclusion group was again subdivided into crowding and without crowding group. The Student's $t$-test was used to analyze the data. In this analytical test the level of significance $p$ value $<0.05$ was considered significant.
Table-1: Comparison of maxillary, mandibular measurements between Class I (normal) occlusion and Class II div 1 malocclusion.

$\begin{array}{lll}\text { Class-I normal } & \text { Class II div } 1 & \text { p Value } \\ \text { occlusion }(\mathrm{n}=50) & \text { malocclusion }(\mathrm{n}=50) & \\ \text { Mean } \pm \mathrm{SD}(\mathrm{mm}) & \text { Mean } \pm \mathrm{SD}(\mathrm{mm}) & \end{array}$

\begin{tabular}{lccc}
\hline $\begin{array}{l}\text { Maxillary } \\
\text { Intercanine width }\end{array}$ & $34.64 \pm 1.69$ & $33.43 \pm 2.79$ & $0.01^{*}$ \\
$\begin{array}{l}\text { Interfirst } \\
\text { premolar width }\end{array}$ & $42.14 \pm 2.59$ & $39.63 \pm 2.90$ & $<0.001^{*}$ \\
$\begin{array}{l}\text { Interfirst molar } \\
\text { width }\end{array}$ & $51.57 \pm 3.61$ & $48.70 \pm 2.87$ & $<0.001^{*}$ \\
$\begin{array}{l}\text { Mandibular } \\
\begin{array}{l}\text { Intercanine width } \\
25.95 \pm 1.82\end{array}\end{array}$ & $25.72 \pm 1.94$ & $0.54 \mathrm{~ns}$ \\
$\begin{array}{l}\text { Interfirst } \\
\text { premolar width }\end{array}$ & $33.98 \pm 2.24$ & $33.52 \pm 2.66$ & $0.34 \mathrm{~ns}$ \\
$\begin{array}{l}\text { interfirst molar } \\
\text { width }\end{array}$ & $44.67 \pm 2.60$ & $42.73 \pm 2.83$ & \\
\hline
\end{tabular}

Table 1 shows maxillary intercanine, interfirst premolar and interfirst molar widths between Class-I and Class-II div-1 were statistically significant and Only mandibular interfirst molar widths were statistically significant between two groups. p value was 0.001 .

Table-2: Comparison of maxillary, mandibular measurements between Class-I (normal) occlusion and Class-II div-2 malocclusion.

$\begin{array}{ll}\text { Class-I normal } & \text { Class II div } 2 \\ \text { occlusion }(\mathrm{n}=50) & \text { malocclusion }(\mathrm{n}=50) \\ \text { Mean } \pm \mathrm{SD}(\mathrm{mm}) & \text { Mean } \pm \mathrm{SD}(\mathrm{mm})\end{array}$

$\mathrm{p}$ Value

Mean $\pm \mathrm{SD}(\mathrm{mm}) \quad$ Mean $\pm \mathrm{SD}(\mathrm{mm})$

\begin{tabular}{llll}
\hline $\begin{array}{l}\text { Maxillary } \\
\text { Intercanine width }\end{array}$ & $34.64 \pm 1.69$ & $33.46 \pm 2.77$ & $0.01^{*}$ \\
$\begin{array}{l}\text { Interfirst } \\
\text { premolar width }\end{array}$ & $42.14 \pm 2.59$ & $33.46 \pm 2.77$ & $<0.001^{*}$ \\
$\begin{array}{l}\text { Interfirst molar } \\
\text { width }\end{array}$ & $51.57 \pm 3.61$ & $50.01 \pm 2.28$ & $0.01^{*}$ \\
$\begin{array}{l}\text { Mandibular } \\
\text { Intercanine width }\end{array}$ & $25.95 \pm 1.82$ & $24.85 \pm 1.94$ & $0.01^{*}$ \\
$\begin{array}{l}\text { Interfirst } \\
\text { premolar width }\end{array}$ & $33.98 \pm 2.24$ & $32.06 \pm 3.61$ & $0.002^{*}$ \\
$\begin{array}{l}\text { interfirst molar } \\
\text { width }\end{array}$ & $44.67 \pm 2.60$ & $43.26 \pm 3.57$ & $0.01^{*}$ \\
\hline
\end{tabular}

Table 2 shows maxillary intercanine, interfirst premolar and interfirst molar widths between Class-I and Class II div 2 malocclusion were statistically significant and also in mandibular measurement. Maxillary measurement of Class-I (normal) occlusion were larger than Class II div 2 malocclusion which is also seen in mandibular measurement. 
Table-3: Comparison of maxillary, mandibular measurements between Class II div 1 malocclusion and class-II div-2 malocclusion.

\begin{tabular}{llll}
\hline $\mathrm{n}=50$ (each group) & $\begin{array}{l}\text { Class II div 1 } \\
\text { malocclusion } \\
\text { Mean } \pm \mathrm{SD}(\mathrm{mm})\end{array}$ & $\begin{array}{l}\text { Class II div } 2 \\
\text { malocclusion } \\
\text { Mean } \pm \mathrm{SD}(\mathrm{mm})\end{array}$ & $\mathrm{p}$ Value \\
\hline $\begin{array}{l}\text { Maxillary } \\
\text { Intercanine width }\end{array}$ & $32.04 \pm 2.43$ & $34.10 \pm 2.08$ & $<0.001^{*}$ \\
$\begin{array}{l}\text { Interfirst } \\
\text { premolar width }\end{array}$ & $38.27 \pm 2.56$ & $39.85 \pm 2.73$ & $0.004^{*}$ \\
$\begin{array}{l}\text { Interfirst molar } \\
\text { width }\end{array}$ & $48.18 \pm 2.50$ & $50.33 \pm 2.05$ & $<0.001^{*}$ \\
$\begin{array}{l}\text { Mandibular } \\
\text { Intercanine width }\end{array}$ & $24.48 \pm 1.70$ & $25.97 \pm 1.88$ & $<0.001^{*}$ \\
$\begin{array}{l}\text { Interfirst } \\
\text { premolar width }\end{array}$ & $32.75 \pm 2.10$ & $34.32 \pm 2.56$ & $0.001^{*}$ \\
$\begin{array}{l}\text { interfirst molar } \\
\text { width }\end{array}$ & $42.45 \pm 2.63$ & $44.68 \pm 2.05$ & $<0.001^{*}$ \\
\hline
\end{tabular}

Table 3 shows maxillary intercanine, interfirst premolar and interfirst molar widths between Class II div 1 malocclusions and class II div 2 malocclusions were statistically significant. and also in mandibular measurement. Maxillary measurements of class II div 1 malocclusion were smaller than Class II div 2 malocclusion which is also seen in mandibular measurement.

Table-4: Comparison of maxillary, mandibular measurements between Class II div 2 malocclusion with crowding and without crowding

\begin{tabular}{llll}
\hline $\mathrm{n}=50$ (each group) & $\begin{array}{l}\text { Class II div 2 } \\
\text { Malocclusion } \\
\text { with crowding } \\
\text { Mean } \pm \text { SD }(\mathrm{mm})\end{array}$ & $\begin{array}{l}\text { Class II div 2 } \\
\text { Malocclusion } \\
\text { without crowding } \\
\text { Mean } \pm \mathrm{SD}(\mathrm{mm})\end{array}$ & $\mathrm{p}$ Value \\
\hline $\begin{array}{l}\text { Maxillary } \\
\text { Intercanine width }\end{array}$ & $33.37 \pm 2.35$ & $32.72 \pm 2.41$ & $0.26 \mathrm{~ns}$ \\
$\begin{array}{l}\text { Interfirst } \\
\text { premolar width }\end{array}$ & $39.22 \pm 2.61$ & $38.81 \pm 2.57$ & $0.28 \mathrm{~ns}$ \\
$\begin{array}{l}\text { Interfirst molar } \\
\text { width }\end{array}$ & $49.25 \pm 2.51$ & $49.17 \pm 2.31$ & $0.73 \mathrm{~ns}$ \\
$\begin{array}{l}\text { Mandibular } \\
\text { Intercanine width }\end{array}$ & $25.21 \pm 2.12$ & $25.45 \pm 1.74$ & $0.61 \mathrm{~ns}$ \\
$\begin{array}{l}\text { Interfirst } \\
\text { premolar width }\end{array}$ & $33.87 \pm 2.81$ & $33.43 \pm 2.00$ & $0.37 \mathrm{~ns}$ \\
$\begin{array}{l}\text { Interfirst molar } \\
\text { width }\end{array}$ & $43.27 \pm 2.75$ & $43.74 \pm 2.45$ & $0.23 \mathrm{~ns}$ \\
\hline
\end{tabular}

Table 4 shows no any statistically significant of maxillary measurements between Class II div 2 malocclusion with crowding and without crowding which is seen in mandibular measurement.

\section{DISCUSSION}

In Bangladesh the incidence of Angle's Class II div 1 malocclusion is $32.74 \%$ (26) and $28.86 \% .27$ The report suggests that the incidence of such class II division 1 highest among the malocclusion groups. Today literature in this field, in context to our country has been very inadequate. A few dissertation works have been done previously which is related to this study in the Department of Orthodontics \& Dentofacial Orthopedics of Dhaka Dental College and Hospital. Thus the proposed study will generate interest among the orthodontists for further study over the transverse discrepancy of our patients and guide them to establish effective treatment strategy and their management.

In our study to compare arch widths, we had slected subjects without posterior crossbite, even in a single tooth, which has ensured accurate measurements of arch widths and no affect the result. In addition to measurements in canine and molar region, arch widths between premolar teeth were also calculated.

The results of this study show that subjects with Class II division 2 malocclusion present significant arch widths differences compared to subjects with Class I (normal) occlusion which supports the hypothesis of this study. Statistically significant differences were found.

Also the results of this study show that subjects with Class II division 1 malocclusion present significant arch widths differences compared to subjects with Class II division 2 malocclusion which support the hypothesis of this study. Statistically significant differences were found.

Our result corroborates with the result of Staley et al. 1985.19 He compared arch widths of 36 Class I (normal) occlusion subjects ( 19 males and 17 females) with 39 Class II division 1 subjects (20 males and 19 females) and reported that subjects with class I (normal) occlusion had larger maxillary intercanine widths than the malocclusion subjects but no differences were found in mandibular intercanine widths. He also reported that subjects with Class I (normal) occlusion had larger maxillary interfirst molar widths.

In this study found maxillary intercanine, interfirst premolar and interfirst molar widths between normal occlusion and Class II div 1 were statistically significant. Normal occlusions were greater than Class II div 1 malocclusions (Table-1).

In this study only mandibular interfirst molar widths were statistically significant between two groups. $\mathrm{p}$ value was 
0.001. But no differences were found in mandibular intercanine and interfirst premolar widths. (Table-2)

Our study showed all measurements were larger in the normal occlusion samples when compared with the Class II division 2 groups. This variations may be due to racial variations.

This study similar the Uysal T et al. 200518 study shows maxillary intercanine, interfirst premolar and interfirst molar widths between Class I normal occlusion and Class II div 2 malocclusion were statistically significant. Maxillary measurement of Class I normal occlusion were larger than Class II div 2 malocclusion. (Table-3)

This study shows mandibular intercanine, interfirst premolar and interfirst molar widths between Class I (normal) occlusion and Class II div 2 malocclusion were statistically significant. Mandibular measurement of Class I normal occlusion were larger than Class II div 2 malocclusion. (Table-4)

Howe et al.28 1983 compared the arch width of Class I (normal) subjects with subjects having gross dental crowding (no Angle's class was given). Maxillary and mandibular canine and molar arch width were significantly larger in the Class I (normal) occlusion in both gender. The result of our study disagreed with the study, no any statistically significant of maxillary measurement between malocclusion with crowding and without crowding. (Table-4)

Our results differ from that of the results of Bishara et al.1996b and Frohlich FJ 1962.22,29 Bishara et al. ${ }^{29}$ 1996b compared dental arch widths differences of 37 Class II division I malocclusion subjects (15 males and 22 females) with 55 Class I (normal) occlusion subjects (28 males and 27 females) at three dentition stages (deciduous, mixed, and permanent dentition). They reported no differences in maxillary and mandibular intercanine widths measurements between the groups. He found no interfirst molar widths differences between the groups. In this study maxillary width larger than mandibular width that was statistically significant.

\section{CONCLUSION}

According to the results of this study in conclusion followings are reached:

Subjects with Class II division 2 had mean maxillary mandibular inter canine, inter first premolar and inter first molar widths larger than Class II division 1 malocclusion.
Mandibular inter canine and inter first premolar widths were similar in Class I (normal) occlusion and Class II div 1 malocclusion. Only mandibular inter first molar widths were larger Class I (normal) occlusion than Class II div 1 malocclusion.

Subjects with class I (normal) occlusion had mean maxillary inter canine, inter first premolar and inter first molar widths larger than Class II division 1 malocclusion. All groups of maxillary arch width have significantly larger arch width than mandibular arch width.

\section{REFERENCES}

1. Ast DB, Carlos JP, Cons DC. Prevalence and characteristics of malocclusion among senior high school students in up-state New York. Am J Orthod. 1965; 51(3):437-445.

2. Moyers RE. Handbook of Orthdontics. Year Book Med Publishers. Chicago, 1988: 191.

3. Willems G, De Bruyne I, Verdonck A, Fieuws S, Carels C. Prevalence of Dentofacial characteristics in a Belgian Orthodontic population. Clin Oral Investig. 2001; 5(2):220-226.

4. Bishara SE, Cummins DM, Jacobsen JR. The morphologic basis for the extraction decision in class II, division 1 malocclusion: a comparative study. Am J Orthod amd Dentofacial Orthop 1995;107(5): 129-135.

5. Carter NE. Dentofacial changes in untreated Class II, division 1 subject. Br J Orthod 1987; 14(4):225-34.

6. Rothstein R, Yoon-Tarlie C. Dental and facial characteristics and growth of males and females with class II, division I malocclusion between the ages of 10 and 14 (revised)-part 1: characteristics of size, form and position. Am J Orthod amd Dentofacial Orthop 2000: 117(4):320-32.

7. Ingerval $\mathrm{B}$, Lennartsson $\mathrm{B}$. Facial skeletal morphology and dental arch dimensions in girls with postnormal occlusions (Angle's class II, division 1) Odont Revy 1972;23(5):63-78.

8. Singh G.Textbook of orthodontics. Jaypee Brothers Medical Publishers (p) Ltd. New Delhi; 2004:279-81.

9. Nakasima A, Ichinose M, Nakata S, Takahama Y. Hereditary factor in the craniofacial morphology of Angle's class II and class III. Am J Orthod Dentofac Ordiop 1982; 111(7):59-66.

10. Bassigny F. Les anomalies orthodontiques. In: Bassigny F. Manual d'orthopedie dento-faciale. Paris: Masson, 1983:92-8.

11. Shaughnessy T, Shire LH. Etiology of Class 11 malocclusions. Ped Dent 1998;10 (5):336-7.

12. Bishara SE, Jacobsen JR, Angelakis D. Post treatment changes in male and female patients: A comparative study. Am J Orthod Dentofac Orthop 1996a; 110(2):624-9.

13. Kirjavainen M, Kirjavainen T, Haavikko K. Changes in dental arch dimensions by use of an orthopedic cervical headgear in class II correction. Am J Orthod Dentofac Ordiop 1997; 111(8):59-66.

14. Orton HS,Battagel JM,Ferguson R,Fernian AM. Distal movement of measuring system and results. Am J Orthod Dentofac Orthop 1996; 109(4):379-85.

15. Elms YN, Buschang PH, Alexander RG. Long term stability of Class II division I, nonextraction cervical face-bow therapy: Model analysis. Am J Orthod Dentofac Orthop 1996;109(4):271-6.

16. Ghafari J Jacobson, Hunt U, Markowitz DL, Shofler FS, Laster LL. Changes of arch width in the early treatment of class 11 , division 1 malocclusions. Am J Orthod Dentofac Orthop 1994; 106(13): 
496-502.

17. Papageorgiou IS, Papadopoulos MA, Zafiriadis A. Dentoalveolar characteristics in Class II division 2 malocclusion. Hel Orthod Rev 1998;1(5):117-34.

18. Uysal T, Memill B, Usumez S, Sari Z. Dental and alveolar arch widths in normal occlusion, Class II division 1 and Class II division 2. Angle Orthod.2005; 75(6):941-7.

19. Staley RN, Stuntz WR, Peterson RN. A comparison of arch widths in adults with normal occulison and adults with class 11 , division 1 malocclusion. Ain J Orthod 1985;88(4):163-9.

20. Buschang PH, Stroud J, Alexander RG. Differences in dental morphology among adult females with untreated class I and class II malocclusion. Eur J Orthod 1994; 16(1):47-52.

21. Toutountzakis N. A study of the relationship between upper dental arch width and other dimensions of the head and face. Orthod Rev 1989;1(4):43-53.

22. Frohlich FJ. Chages in untreated class II type malocclusions. Angle Orthod. 1962;32(8):167-79

23. Baccetti T ,Tollaro I, Franchi L, Tanasescu CD. Role of posterior transverse interarch discrepancy in class 11, division I malocclusion during the mixed dentition phase. Am J Orthod Dentofac
Orthop1996; 110(2):417-22.

24. Rahman MM, Dissertation for FCPS part-II exam. Estimation of arch form, arch width and arch length in normal occlusion, at Dhaka dental college and Hospital,2007:

25. Islam MM, Dissertation for FCPS part-II exam, Comparative study of arch widths of Bangladeshi subject with normal occlusion and class II division I malocclusion, at Dhaka dental college and Hospital ,2011:

26. Ahmed N, Chowdhury K. Prevalence of malocclusion and its etiological factors. J of Oral Health $1996 ; 2$ (2):12-16.

27. Hossain MZ, Hague S, Yasmin S, Haque A, Bihar R, Haq ME. Prevelence of malocclusion and Treatment facilities at Dhaka Dental College and Hospital. J of Oral Health. 1996; 3 (1): 24-29.

28. Howe DA, Millar TJ, Schilke P, \& Walmsley CM. Longitudinal comparisons of dental arch changes in normal and untreated Class II, division 1 subjects and their clinical implications. Am J Orthod Dentofac Orthop.1983;110 (3):483.

29. Bishara SE, Bayati P, Jacobsen JR. Longitudinal comparisons of dental arch changes in normal and untreated Class II, division 1 subjects and their clinical implications. Am J Orthod Dentofac Orthop 1996b;110 (3):483

\title{
Correspondence
}

\author{
Dr. Md. Masud Rana BDS, FCPS \\ Assistant Profressor \\ Department of Orthodontics \\ Marks Dental College and hospital. \\ E-mail : masudr37@yahoo.com
}

Cell : +8801716377112 